\title{
Instructor-led oral debriefing technique in clinical nursing simulation: integrative review
}

\author{
Técnica de debriefing oral orientado por instrutor na simulação clínica em enfermagem: revisão integrativa
}

Técnica de debriefing oral orientado por instructor en la simulación clínica en enfermería: revisión integrativa

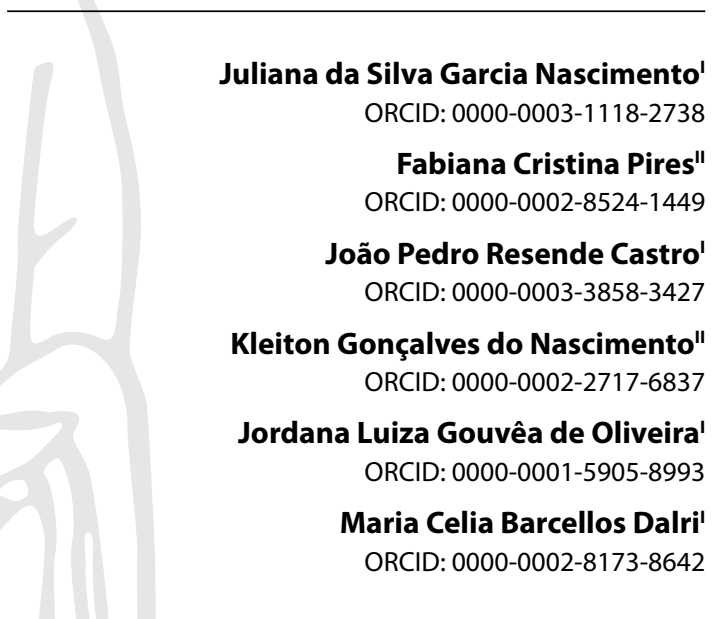

'Universidade de São Paulo. Ribeirão Preto, São Paulo, Brazil. "Universidade Federal do Triângulo Mineiro. Uberaba, Minas Gerais, Brazil.

How to cite this article: Nascimento JSG, Pires FC, Castro JPR, Nascimento KG, Oliveira JLG, Dalri MCB. Oral debriefing technique oriented by instructor in clinical nursing simulation: integrative review. Rev Bras Enferm. 2021;74(Suppl 5):e20190750. https://doi.org/10.1590/0034-7167-2019-0750

Corresponding author: Juliana da Silva Garcia Nascimento E-mail: mestradounesp28@yahoo.com.br

EDITOR IN CHIEF: Dulce Barbosa ASSOCIATE EDITOR: Elisabete Salvador

Submission: $01-22-2020$

Approval: 11-01-2020

\begin{abstract}
Objective: To analyze available scientific evidence in literature pertaining to the elements that make the instructor-led oral debriefing technique in clinical nursing simulation feasible. Methods: An Integrative literature review along the following information sources: PubMed", Scopus, Web of Science, Literatura Latino-Americana e do Caribe em Ciências da Saúde (LILACS) [Latin American and Caribbean Health Sciences Literature], Cumulative Index to Nursing and Allied Health Literature (CINAHL), and Educational Resources Information Centre (ERIC). Results: 284 studies were identified, and 5 composed the sample. Four elements constitute oral debriefing: characteristics of the instructor; discussion format, debriefing structure; and time frame. The main benefit was to develop cognitive and psychomotor skills; and the challenge was to establish training for instructors. The studies showed high methodological quality. Final Considerations: The scientific deepening as to the elements, benefits, and challenges of oral debriefing enables its execution and offers quality to the nursing process. Descriptors: Students; Simulation; Nursing Education; Nursing; Simulation Training.
\end{abstract}

\section{RESUMO}

Objetivo: Analisar as evidências científicas disponíveis na literatura sobre os elementos que viabilizam a técnica de debriefing oral orientado por instrutor na simulação clínica em enfermagem. Métodos: Revisão integrativa da literatura realizada nas fontes de informação: PubMed', Scopus, Web of Science, Literatura Latino-Americana e do Caribe em Ciências da Saúde (LILACS), Cumulative Index to Nursing and Allied Health Literature (CINAHL) e Educational Resources Information Centre (ERIC). Resultados: Identificaram-se 284 estudos, e 5 compuseram a amostra. Quatro elementos constituem o debriefing oral: características do instrutor; formato da discussão, estrutura do debriefing; e tempo. O principal benefício foi desenvolver habilidades cognitivas e psicomotoras; e o desafio, estabelecer treinamento aos instrutores. Os estudos apresentaram alta qualidade metodológica. Considerações finais: O aprofundamento científico quanto aos elementos, benefícios e desafios do debriefing oral possibilita sua execução e confere qualidade ao processo para enfermagem.

Descritores: Estudantes; Simulação; Educação em Enfermagem; Enfermagem; Treinamento por Simulação.

\section{RESUMEN}

Objetivo: Analizar las evidencias científicas disponibles en la literatura sobre los elementos que hacen viable la técnica de debriefing oral orientado por instructor en la simulación clínica en enfermería. Métodos: Revisión integrativa de la literatura realizada en las fuentes de información: PubMed', Scopus, Web of Science, Literatura Latinoamericana y del Caribe en Ciencias de Salud (LILACS), Cumulative Index to Nursing and Allied Health Literature (CINAHL) y Educational Resources Information Centre (ERIC). Resultados: Se identificaron 284 estudios, y 5 compusieron la muestra. Cuatro elementos constituyen el debriefing oral: características del instructor; formato de la discusión, estructura del debriefing; y tiempo. El principal beneficio ha sido desarrollar habilidades cognitivas y psicomotrices; y el desafío, establecer entrenamiento a los instructores. Los estudios presentaron alta calidad metodológica. Consideraciones finales: La profundización científica cuanto a los elementos, beneficios y desafíos del debriefing oral posibilita su ejecución y confiere calidad al proceso para enfermería. Descriptores: Estudiantes; Simulación; Educación en Enfermería; Enfermería; Entrenamiento por Simulación. 


\section{INTRODUCTION}

Traditional teaching and learning approaches still permeate the health field, having its foundations on memorization of concepts and the devaluation of problem solving, which has been shown to be less effective than other strategies for the development of clinical skills and critical thinking of students ${ }^{(1-3)}$.

With the intention of adopting more effective pedagogical methods for teaching in nursing, simulation has gained room, as it is characterized as a strategy that accurately replicates an event, situation, environment, or clinical scenario ${ }^{(4)}$, being considered a viable solution to make the teaching and learning process reflective, active, and more meaningful(5).

Debriefing, on the other hand, is an essential phase of the simulation, characterized as a planned reflection session which aims to improve participants future performance ${ }^{(6)}$. In the last decade, more than 30 methods and 10 debriefing techniques have emerged; however, few well-designed studies in nursing have described the best way to apply them to the teaching and learning process ${ }^{(7)}$.

Of the existing debriefing techniques, instructor-led oral debriefing, considered a traditional method, addresses a verbal discussion facilitated by a single instructor, usually in person, which requires that person's preparation and competence ${ }^{(8)}$.

Although this technique is widely practiced in nursing simulation and there are studies that compare its effectiveness to that of other debriefing techniques, there is an important gap in the literature regarding the ideal way to execute $\mathrm{it}^{(8-9)}$.

When we understand that debriefing promotes the development of knowledge, skills, and attitudes, with an emphasis on best practices that promote safety and quality care for the patient, the main consequence of not acquiring a standard to perform it, or a script to guide the discussion, acts as a deficiency in obtaining reliable learning results ${ }^{(6)}$.

Therefore, it becomes useful for the teaching and learning process in nursing simulation to scientifically deepen the necessary elements to make the instructor-led oral debriefing technique feasible, in a clear and effective manner ${ }^{(7)}$.

\section{OBJECTIVE}

To analyze available scientific evidence in literature pertaining to the elements that make the instructor-led oral debriefing technique in clinical nursing simulation feasible.

\section{METHODS}

\section{Ethical aspects}

As it is a literature review study, with no involvement of human beings, it does not require approval by the Research Ethics Committee.

\section{Type of study}

It is an integrative literature review, which aims to identify and understand the elements that enable the effectiveness in performing the instructor-led oral debriefing technique. This method allows analyzing of scientific literature and providing a broad understanding of the object of study, providing a scientific evidence-based contribution to the nursing practice ${ }^{(10)}$.

\section{Methodological Procedures}

We determined the execution of the following steps: identify the theme and select the guiding research question; establish criteria for inclusion and exclusion of studies; define the information to be extracted from the selected studies; evaluate the studies included in the integrative review; and interpret the results and present the synthesis of the knowledge ${ }^{(10)}$.

\section{Data collection and organization}

In the first stage, the instructor-led oral debriefing technique was established as a review topic, and the research question was selected through the Patient-Intervention-Comparison-Outcomes (PICO) strategy, with emphasis on the following question: "What evidence is available in the literature on the elements that make the instructor-led oral debriefing technique viable for nursing students in clinical simulation?" Nursing students stood out, as an acronym " $\mathrm{P}$ ", referring to the target population; as an acronym "I" (intervention), the elements that make up the instructor-led oral debriefing technique; and the acronym " $\mathrm{O}$ " (outcome), was represented in this question by the teaching and learning process, through clinical simulation.

After defining the guiding question, the inclusion and exclusion criteria of the studies were defined. We included: primary studies that answered the guiding question, without delimiting the time frame and language, published in scientific journals, and electronically available. Literature reviews, case studies, dissertations, theses, monographs, and abstracts published in annals of events were excluded.

Then, the studies were searched in September 2020, in the following sources of information: PubMed ${ }^{\circ}$, Scopus, Web of Science, Literatura Latino-Americana e do Caribe em Ciências da Saúde (LILACS) [Latin American and Caribbean Health Sciences Literature], Cumulative Index to Nursing and Allied Health Literature (CINAHL), and Educational Resources Information Centre (ERIC). To ensure a more targeted search, considering the need to specifically identify the instructor-led oral debriefing technique, the keywords "Debriefing" and "Instructor-led debriefing" were used. The search strategies outlined according to each library and database - and validated by a librarian - as well as the descriptors and keywords are shown in Chart 1, below.

\section{Data analysis}

After data collection, the studies were submitted to the first selection stage, by applying the previously defined inclusion and exclusion criteria. For this, two professionals independently read titles and abstracts, using the Rayyan review application, which eliminates duplicate articles, speeds up initial screening by using a reliable semi-automatic process, and incorporates a high level of usability and effectiveness. in the process ${ }^{(11)}$. 
Chart 1 - Characterization of the process of searching for the studies that comprised the sample of the present integrative review, 2020

\begin{tabular}{|c|c|c|}
\hline $\begin{array}{l}\text { Libraries and } \\
\text { databases }\end{array}$ & Descriptors and keywords & Search strategy \\
\hline PubMed $^{\circ}$ & $\begin{array}{l}\text { MESH: "Students, Nursing"; "Simulation } \\
\text { Training" } \\
\text { Keywords: Debriefing; } \\
\text { "Instructor-led debriefing" }\end{array}$ & $\begin{array}{l}\text { (("Students, Nursing" [MESH] OR "Pupil Nurses" [TIAB] OR "Student, Nursing" [TIAB] OR } \\
\text { "Nurses, Pupil" [TIAB] OR "Nurse, Pupil" [TIAB] OR "Pupil Nurse" [TIAB] OR "Nursing Student" } \\
\text { [TIAB] OR "Nursing Students" [TIAB] AND Debriefing AND "Instructor-led debriefing" AND } \\
\text { "Simulation Training" [MESH] OR "Training, Simulation" [TIAB])) } \\
\text { Search limiters: not used }\end{array}$ \\
\hline Scopus & $\begin{array}{l}\text { MESH: "Students, Nursing" } \\
\text { "Simulation Training" } \\
\text { Keywords: Debriefing; } \\
\text { "Instructor-led debriefing" }\end{array}$ & $\begin{array}{l}\text { TITLE-ABS-KEY ("Students, Nursing" OR"Pupil Nurses" OR"Student, Nursing" OR"Nurses, Pupil" OR } \\
\text { "Nurse, Pupil" OR"Pupil Nurse" OR"Nursing Student"OR"Nursing Students") AND (Debriefing) AND } \\
\text { ("Instructor-led debriefing") AND ("Simulation Training" OR "Training, Simulation") } \\
\text { Search limiters: not used }\end{array}$ \\
\hline CINAHL & $\begin{array}{l}\text { Titles } \\
\text { "Students, Nursing"; Simulations } \\
\text { Keywords: Debriefing;"Instructor-led } \\
\text { debriefing" }\end{array}$ & $\begin{array}{l}\text { (("Students, Nursing") AND (Debriefing) AND ("Instructor-led debriefing") AND (Simulations)) } \\
\text { Search limiters: not used }\end{array}$ \\
\hline LILACS & $\begin{array}{l}\text { DeCs } \\
\text { "Students, Nursing" Simulation and its } \\
\text { Portuguese and Spanish versions } \\
\text { Keywords: Debriefing" "Instructor-led } \\
\text { debriefing" and its Portuguese and } \\
\text { Spanish versions }\end{array}$ & $\begin{array}{l}\text { ("Students, Nursing") AND (Debriefing) AND ("Instructor-led debriefing") AND (Simulation) } \\
\text { ("Estudiantes de Enfermería") AND (Interrogatorio) AND ("Interrogatorio dirigido por } \\
\text { instructor") AND (Simulación) } \\
\text { (("Estudantes de Enfermagem") AND (Debriefing) AND ("Debriefing orientado por } \\
\text { instrutor") AND (Simulação)) } \\
\text { Search limiters: not used }\end{array}$ \\
\hline $\begin{array}{l}\text { Web of } \\
\text { Science }\end{array}$ & $\begin{array}{l}\text { "Students, Nursing"; "Simulation } \\
\text { Training" } \\
\text { Keywords: Debriefing;"Instructor-led } \\
\text { debriefing" }\end{array}$ & $\begin{array}{l}\text { TS=(Students, Nursing AND Debriefing AND Instructor-led debriefing AND Simulation } \\
\text { Training) } \\
\text { Indexes=SCI-EXPANDED, SSCI, A\&HCI, CPCI-S, CPCI-SSH, ESCI Allotted time=Every year }\end{array}$ \\
\hline ERIC & $\begin{array}{l}\text { "Students, Nursing"; Simulations } \\
\text { Keywords: Debriefing; "Instructor-led } \\
\text { debriefing" }\end{array}$ & $\begin{array}{l}\text { (("Students, Nursing") AND (Debriefing) AND ("Instructor-led debriefing") AND (Simulations)) } \\
\text { Search limiters: not used }\end{array}$ \\
\hline
\end{tabular}

Notes: MESH: Medical Subjects Headings; CINAHL: Cumulative Index to Nursing and Allied Health Literature; LILACS: Literatura Latino-Americana e do Caribe em Ciências da Saúde; DeCs: Health Sciences Descriptors; ERIC: Educational Resources Information Centre.

After titles and abstracts selection, the nine studies that caused divergence among the researchers were handed over to a third professional, responsible for making the inclusion or exclusion decision; then, the full reading of the studies was performed to define the final sample. It is worth clarifying that, due to the scarcity of scientific studies that address the elements to make this debriefing technique feasible, an analysis of the references of the included articles was carried out, without new articles being added for the final analysis. To extract the information, the following items from a validated instrument ${ }^{(12)}$ were used: identification of the article, by title, authors, country of origin, language, and year of publication, objectives, methodological outline and results; and the Evidence Level ${ }^{(13)}$ was classified.

The critical assessment of the quality of the articles that composed the sample was carried out by two researchers, independently, according to the evaluation instrument of the Joanna Brigg ${ }^{(14)}$ Institute, specific for quasi-experimental studies and composed of nine questions that address the following: (1) clarity about cause and effect; (2) verification of the similarity of the characteristics between study participants; (3) similarity in the treatment/intervention of the participants; (4) use of a control group; (5) existence of multiple measurements over time of pre-intervention and post-intervention results; (6) complete follow-up or adequate description/analysis of differences between groups; (7) equal measurement of participants' results; (8) reliable measuring of results; (9) use of appropriate statistical analysis. The evaluation fields for each question include the answers "yes" or "no"; and the more questions are answered with "yes", the better the methodological quality of the study.

\section{RESULTS}

At first, 284 studies were selected. Based on the Preferred Reporting Items for Systematic Reviews and Meta-Analyzes (PRISMA) (15), the article sample selection flow was shown, as seen in Figure 1.

To interpret the results and present the synthesis of knowledge, five primary studies, detailed in Chart 2, were considered eligible for the sample of this integrative review.

Three categories were established on the instructor-led oral debriefing technique, called: Component elements; Benefits; and Challenges for adoption. The elements were highlighted in Chart 3, below.

The category called"Benefits of adopting the instructor-led oral debriefing technique" showed the following potential: (1) development of cognitive and psychomotor skills in nursing ${ }^{(7,9,16-18)}$; (2) immediate correction of errors with the opportunity for reflection

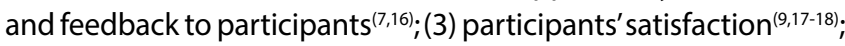
(4) feedback directed at performance gaps capable of causing change in practice ${ }^{(7,9) ;}(5)$ interaction between instructor and students, with clarifications and feedback for the practice $e^{(9,17-18)}$; (6) active listening on the instructor's behalf towards the student, including non-judgmental behavior analysis, and encouraging active learning ${ }^{(17)}$. 


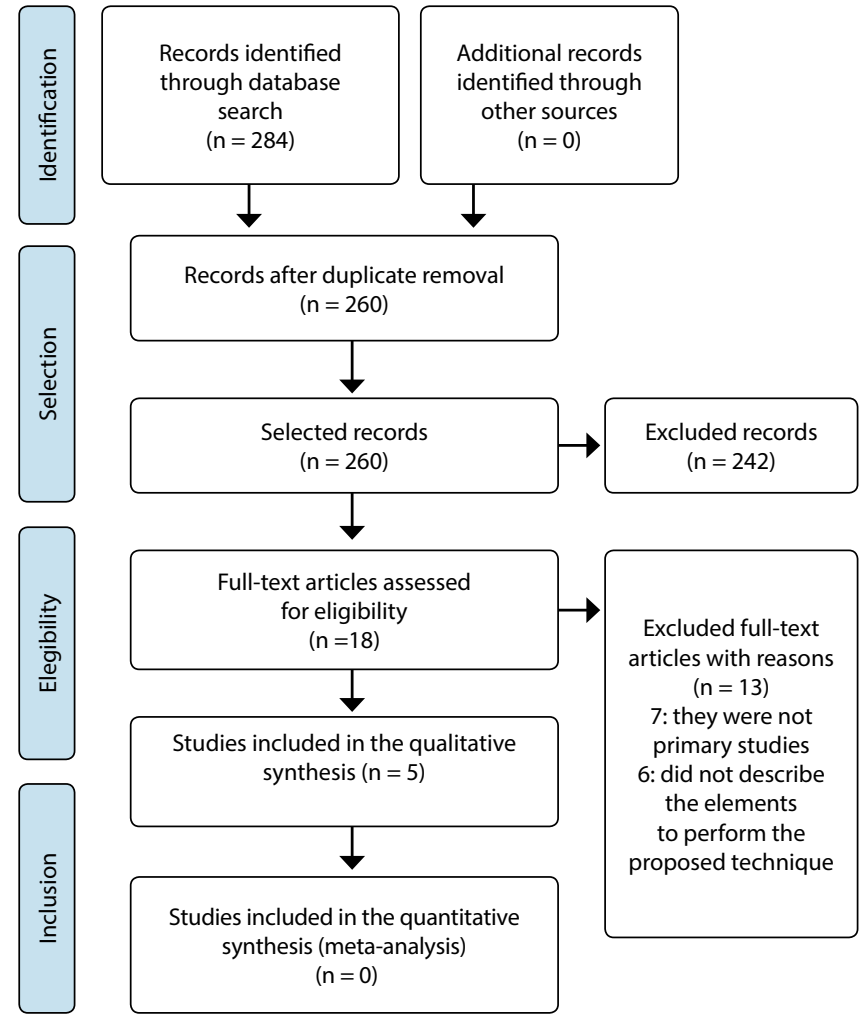

Source: Moher et al. ${ }^{(15)}$.

Figure 1 - Presentation of the selection of studies to compose the sample of the integrative review according to Preferred Reporting Items for Systematic Reviews and Meta-Analyzes (PRISMA), 2020
The category "Challenges for adopting the instructor-led oral debriefing technique" highlighted: (1) obtaining a properly trained instructor to perform oral debriefing ${ }^{(7,9) ;}$; (2) expansion of curricula based on clinical simulation in nursing schools, which generally exceeds the institutional capacity to prepare instructors ${ }^{(7,9,16-18) \text {; }}$ (3) students' difficulty in being expressive and participate in this debriefing ${ }^{(7,9,17)}$; (4) the student may feel reprimanded, judged, and ridiculed by the instructor, in front of his colleagues, a factor that increases his stress ${ }^{(17-18)}$.

Chart 4, below, shows the critical appreciation of the quality of the articles that made up the sample, using the Joanna Briggs ${ }^{(14)}$ evaluation instrument.

\section{DISCUSSION}

Although several scientific studies address the instructor-led oral debriefing technique and consider it traditional, research that describe its elements are still incipient, configuring an important gap, also demonstrated by the small sample selected for this research.

The publications that address the elements pertinent to this technique are recent - they start from $2015^{(18)}$, and the majority are from $2018^{(7,16-17)}$. All the studies that made up this sample are quasi-experimental and performed in South Korea, aiming to compare the instructor-led oral debriefing technique with other debriefing techniques. These studies have pointed out, for the most part, that instructor-led oral debriefing is effective for the teaching and learning process in nursing, regarding the development of cognitive, psychomotor, and behavioral skills.

Chart 2 - Characterization of the studies included in the integrative review, 2020

\begin{tabular}{|c|c|c|c|c|c|}
\hline Title & $\mid \begin{array}{c}\text { Year } \\
\text { Country }\end{array}$ & $\begin{array}{l}\text { Outline/number of } \\
\text { participants }\end{array}$ & Interventions & Outcomes & $\begin{array}{l}\text { Levels of } \\
\text { Evidence }\end{array}$ \\
\hline $\begin{array}{l}\text { Comparison of student } \\
\text { self-debriefing versus } \\
\text { instructor debriefing in } \\
\text { nursing simulation: A quasi- } \\
\text { experimental study }{ }^{(7)}\end{array}$ & $\begin{array}{l}2018 \\
\text { South } \\
\text { Korea }\end{array}$ & $\begin{array}{l}\text { Quasi-experimental } \\
\text { study/ } \\
n=63 \text { nursing } \\
\text { students }\end{array}$ & $\begin{array}{l}\text { Instructor-led oral } \\
\text { debriefing (control } \\
\text { group) versus self- } \\
\text { debriefing (intervention } \\
\text { group) }\end{array}$ & $\begin{array}{l}\text { Instructor-led oral debriefing proved effective } \\
\text { in solving nursing problems and satisfying } \\
\text { participants. }\end{array}$ & 3 \\
\hline $\begin{array}{l}\text { Comparison of instructor-led } \\
\text { versus peer-led debriefing in } \\
\text { nursing students }{ }^{(9)}\end{array}$ & $\begin{array}{l}2016 \\
\text { South } \\
\text { Korea }\end{array}$ & $\begin{array}{l}\text { Quasi-experimental } \\
\text { study of the before } \\
\text { and after type/ } \\
\mathrm{n}=65 \text { nursing } \\
\text { students }\end{array}$ & $\begin{array}{l}\text { Oral debriefing with } \\
\text { instructor (control } \\
\text { group) versus peer } \\
\text { debriefing (intervention } \\
\text { group) }\end{array}$ & $\begin{array}{l}\text { Instructor-led oral debriefing proved to be } \\
\text { more effective compared to the peer- } \\
\text { led debriefing. Instructor-led debriefing } \\
\text { is an effective method for improving } \\
\text { cardiopulmonary resuscitation skills. }\end{array}$ & 3 \\
\hline $\begin{array}{l}\text { Instructor-led vs. peer-led } \\
\text { debriefing in preoperative } \\
\text { care simulation using } \\
\text { standardized patients } \\
{ }^{(16)}\end{array}$ & $\begin{array}{l}2018 \\
\text { South } \\
\text { Korea }\end{array}$ & $\begin{array}{l}\text { Quasi-experimental } \\
\text { study; of the before } \\
\text { and after type/ } \\
\mathrm{n}=57 \text { nursing } \\
\text { students }\end{array}$ & $\begin{array}{l}\text { Instructor-led oral } \\
\text { debriefing versus peer- } \\
\text { led debriefing }\end{array}$ & $\begin{array}{l}\text { The nursing skills for preoperative care ( } p \\
<0.001 \text { ) and the quality of debriefing ( }<< \\
0.001 \text { ) were statistically higher in the group } \\
\text { of instructor-led oral debriefing techniques. } \\
\text { Oral debriefing with an instructor is effective } \\
\text { for learning in nursing. }\end{array}$ & 3 \\
\hline $\begin{array}{l}\text { Peer-Led Written Debriefing } \\
\text { Versus Instructor-led Oral } \\
\text { Debriefing: Using Multimode } \\
\text { Simulation }^{(17)}\end{array}$ & $\begin{array}{l}2018 \\
\text { South } \\
\text { Korea }\end{array}$ & $\begin{array}{l}\text { Quasi-experimental } \\
\text { study/ } \\
\mathrm{n}=122 \text { nursing } \\
\text { students }\end{array}$ & $\begin{array}{l}\text { Instructor-led oral } \\
\text { debriefing (control } \\
\text { group) versus written } \\
\text { peer-led debriefing }\end{array}$ & $\begin{array}{l}\text { As for knowledge, there was no statistically } \\
\text { significant difference between the two } \\
\text { groups ( } p=0.940) \text {, but self-confidence and } \\
\text { satisfaction were better evaluated in the } \\
\text { control group ( } p=0.010) \text {. Instructor-led oral } \\
\text { debriefing can be as effective as written peer } \\
\text { debriefing }\end{array}$ & 3 \\
\hline $\begin{array}{l}\text { The Importance of Debriefing } \\
\text { in Simulation-Based } \\
\text { Learning: Comparison } \\
\text { Between Debriefing and No } \\
\text { Debriefing }{ }^{(18)}\end{array}$ & $\begin{array}{l}2015 \\
\text { South } \\
\text { Korea }\end{array}$ & $\begin{array}{l}\text { Quasi-experimental } \\
\text { study/ } \\
n=49 \text { nursing } \\
\text { students }\end{array}$ & $\begin{array}{l}\text { Instructor-led oral } \\
\text { debriefing (intervention } \\
\text { group) versus no } \\
\text { debriefing (control } \\
\text { group) }\end{array}$ & $\begin{array}{l}\text { There was a statistically significant difference } \\
\text { for the group that used debriefing regarding } \\
\text { clinical performance competence }(p<0.001) \text {, } \\
\text { nursing skills }(p=0.022) \text {, task management }(p \\
<0.001) \text {, decision making }(p<0.001) \text {, teamwork } \\
(p<0.001) \text { and communication }(p<0.001) \text {. }\end{array}$ & 3 \\
\hline
\end{tabular}


Chart 3 - Characterization of the elements of the instructor-led oral debriefing technique, 2020

\begin{tabular}{|c|c|}
\hline Elements & Description \\
\hline $\begin{array}{l}\text { Instructor } \\
\text { characteristics }\end{array}$ & $\begin{array}{l}\text { Requires the presence of an instructor/facilitator, formally and properly trained, and the instructor who conducts the simulation must } \\
\text { also provide debriefing } g^{(7,9,16)} \text {. }\end{array}$ \\
\hline $\begin{array}{l}\text { Discussion } \\
\text { format }\end{array}$ & Face-to-face discussion with a relationship management model ${ }^{(7,9,16-18)}$. \\
\hline $\begin{array}{l}\text { Structure/ } \\
\text { procedure }\end{array}$ & $\begin{array}{l}\text { Oral debriefing technique led by an instructor with a structured method in three phases: gather; analyze and summarize (G.A.S debriefing*) })^{(7,9,17)} \text {. } \\
\text { G.A.S debriefing, a structured method of debriefing, has been recommended by the literature as the main procedure to enable the instructor-led } \\
\text { oral debriefing technique, especially in nursing experiences that involve the teaching and learning process of urgency and emergency } y^{(7,9,17)} \text {. } \\
\text { In this method, the instructor starts the "gather" phase, reassuring the participants and encouraging them to expose their feelings about the } \\
\text { scene experienced in the clinical simulation. Then, it proceeds to the analysis phase, which addresses the articulation of the desired theoretical } \\
\text { framework and the experience, consolidating the desired knowledge. Finally, the summary phase, in which some thought is given on the } \\
\text { strengths experienced and those that need improvement, reflecting how this learning can be applied in real future situations }{ }^{(7,9,17)} \text {. }\end{array}$ \\
\hline Time frame & Two to three times higher than the scenario ${ }^{(16,18)}$. \\
\hline
\end{tabular}

Note: ${ }^{*}$ G.A.S debriefing is formed of three steps: gather $(G)$, analyze $(A)$ and summarize $(S)$.

Chart 4 - Quality assessment of quasi-experimental articles that made up the sample, 2020

\begin{tabular}{|c|c|c|c|c|c|}
\hline Question & Study 7 & Study 9 & Study 16 & Study 17 & Study 18 \\
\hline $\begin{array}{l}\text { 1. Is it clear in the study what is the "cause" and what is the "effect" (i.e. } \\
\text { there is no confusion about which variable comes first)? }\end{array}$ & Yes & Yes & Yes & Yes & Yes \\
\hline 2. Were the participants included in any similar comparisons? & Yes & Yes & Yes & Yes & Yes \\
\hline $\begin{array}{l}\text { 3. Were the participants included in any comparisons receiving similar } \\
\text { treatment/care, other than the exposure or intervention of interest? }\end{array}$ & Yes & Yes & Yes & Yes & Yes \\
\hline 4. Was there a control group? & Yes & Yes & Yes & Yes & Yes \\
\hline $\begin{array}{l}\text { 5. Were there multiple measurements of the outcome both pre and } \\
\text { post the intervention/exposure? }\end{array}$ & No & No & No & No & No \\
\hline $\begin{array}{l}\text { 6. Was follow up complete and, if not, were differences between groups } \\
\text { in terms of their follow up adequately described and analyzed? }\end{array}$ & Yes & Yes & Yes & Yes & Yes \\
\hline $\begin{array}{l}\text { 7. Were the outcomes of participants included in any comparisons } \\
\text { measured in the same way? }\end{array}$ & Yes & Yes & Yes & Yes & Yes \\
\hline 8. Were outcomes measured in a reliable way? & Yes & Yes & Yes & Yes & Yes \\
\hline 9. Was appropriate statistical analysis used? & Yes & Yes & Yes & Yes & Yes \\
\hline
\end{tabular}

Regarding the instructor-led oral debriefing technique, the studies were categorized into: Component elements; Benefits; and Challenges for adoption. In the literature, four main elements necessary to enable the proposed technique were identified: characteristics of the instructor; discussion format, debriefing structure; and time frame.

The oral debriefing technique is characterized by the inclusion of only one instructor during the reflection process, who must be responsible for conducting this stage of the simulation, through prior and adequate training. Since debriefing is a process of reflection that allows the integration of knowledge, skills, and attitudes to the participants, it requires, for this, that teachers and instructors in general be trained to plan and execute it, since, without the necessary preparation, the parties involved do not take advantage of all its potential(19).

After effective training to perform oral debriefing, instructors become more confident, comfortable, and likely to develop an effective relationship with students ${ }^{(20)}$. An instructor adequately prepared for the technique is able to establish an appropriate discussion with the participants, causing the development of reflection and behavioral change, and not just offering corrective feedback on performance. However, scientific studies in the literature that both specifically address the training of instructors for debriefing, performed by a trained and untrained instructor, and compare this technique ${ }^{(20-21)}$, are only now beginning to appear.
It was also identified that the face-to-face discussion was the preferred format for reflection in the instructor-led oral debriefing technique. A literature review study conducted in 2018 , with a sample of 34 articles, aimed to identify whether the relationship between instructor and students during the execution of face-to-face debriefing contributes to the development of a favorable learning environment. It was identified that there was an importance in adopting a conceptual structure to support this process, called "Relationship Management Model", composed of face-to-face relationships, rights and objectives, and which is capable of improving learning results in the short term ${ }^{(22)}$.

The face-to-face aspect of a face-to-face debriefing is related to issues such as respect and is closely linked to a person's sense of identity as an individual and/or group member. On the other hand, rights are related to the student's expectations of the instructor (e.g., to be treated fairly), and the objectives refer to specific tasks that the participants have during the simulation, emphasizing that failures in carrying out the activity can lead to to the participant's frustration. If these criterion are misaligned in face-to-face debriefing, their quality is seriously put at risk ${ }^{(22)}$.

Another important element to perform the instructor-led oral debriefing technique is the adoption of a structure. The studies that made up the sample of the present review pointed at the Structured and Supported (G.A.S debriefing) debriefing as the main 
method of debriefing to support the proposed technique. It was developed by the Winter Institute for Simulation, Education, and Research, at the University of Pittsburgh, in partnership with the American Heart Association, in 2009, initially for debriefing in Advanced Life Support and, soon after, expanded to various situations and contexts of simulation, for the ease of performing ${ }^{(23)}$.

The Structured and Supported debriefing is known as G.A.S debriefing, as it covers three steps: gather (G), analyze (A) and summarize $(S)^{(22)}$. During the first phase, the information is gathered by the instructor and the participants are reassured, given that they will expose their feelings about the proposed experience; in the second phase, the information is analyzed and aligned with the relevant theoretical framework; and the third phase addresses the summary of events, as well as a survey of positive aspects and those that should be improved ${ }^{(24)}$. Thus, the instructor can use this method to conduct the discussion with the participants, carrying out each phase in person and verbally.

The time frame was considered as an element that makes up the instructor-led oral debriefing technique, requiring two to three times more time than for the simulation scenario. The reason lies in the fact that oral debriefing requires the formulation of questions aimed at reflection, basing it on the previously determined debriefing structure, which requires time to raise awareness and reassure the participants, alignment with the proposed theoretical framework, and synthesis of the knowledge. This technique is performed during or, preferably, shortly after the simulation experience, with time being a critical element for its quality ${ }^{(7)}$.

More benefits than challenges were identified for adopting the instructor-led oral debriefing technique. The main benefit was characterized by the development of cognitive and psychomotor skills in nursing, more significantly in this debriefing technique than in others, such as peer-led debriefing, performed among pairs of students, or self-debriefing, performed by the student himself, without the instructor.

An experimental study carried out with 65 Nursing students at a Korean university, with the objective of investigating the effectiveness of instructor-led oral debriefing, compared to that performed by peers, found that the quality of cognitive and psychomotor skills for cardiopulmonary resuscitation and satisfaction with the simulation were greater in the debriefing technique performed with an instructor. This was considered effective in terms of skills for cardiopulmonary resuscitation and the satisfaction of nursing students ${ }^{(9)}$.

This result corroborates a survey conducted in South Korea with 57 Nursing students, who also compared the instructor-led oral debriefing technique and the technique which is performed by peers, regarding the nursing skills for preoperative care, knowledge, self-confidence, and quality of the debriefing. The results were statistically significant in the group of oral debriefing technique with an instructor ${ }^{(16)}$.

The association of this technique with other debriefing techniques, such as self-debriefing, was indicated in a quasi-experimental study, which addressed 123 Nursing students from South Korea, with the aim of comparing the efficacy of both. Favorable aspects were noted in both techniques, and their articulation was suggested to maximize satisfaction and favor the teaching and learning process in nursing ${ }^{(7)}$.
The main challenge highlighted by the literature to perform the instructor-led oral debriefing technique was the need to obtain adequate training for the facilitator, given the large number of students in the Nursing schools, which exceeds the institutions capacity to adequately prepare professionals.

In this sense, a study of mixed methods carried out in American universities described the simulation practices in detail of professors in undergraduate Nursing courses, highlighting the four main challenges to perform the debriefing: time frame, training, resistance, and faculty fatigue. This research pointed out that the limited finances of universities, the scarce time to prepare instructors, and the excessive number of students hinder the performance of an oral debriefing done by a qualified instructor, causing tiredness and resistance on the part of the professionals involved ${ }^{(25)}$.

Although it was not widely highlighted, it is worth noting that the difficulty to invest in the proper training of instructors for debriefing can trigger another challenge evidenced in this research: the fact that the student feels reprimanded, judged, and ridiculed by the instructor in front of colleagues, which causes stress for them ${ }^{(7,9,16,26)}$.

Thus, it is also a challenge for educational institutions to find solutions to promote training and prepare instructors for nursing debriefing, generating a protection factor, which prevents stressful and unfavorable situations to the nursing teaching and learning process $^{(27-31)}$.

The critical evaluation of the studies that comprised the sample of the present integrative review revealed a high methodological quality $^{(14)}$ in its entirety, being that only one evaluation criteria was not considered by the articles in question, characterized by the performance of multiple measurements of the results over time.

However, it is important to measure the results over time in a scientific study, to evidence whether there was a change in the a priori outcomes and to explore these changes during a certain period ${ }^{(14)}$.

From this perspective, obtaining a credible sample of scientific studies is reflected in rigor and greater reliability of the results obtained, which minimize the presence of bias and invalid interpretations, as well as enabling the information produced to have a robust impact for the knowledge to be compiled ${ }^{(32)}$.

In the development of research in the nursing area, careful care in selecting the method and scientific rigor in following the recommendations for each type of study are essential to produce the best evidence and obtain better results in clinical practice ${ }^{(33)}$. Thus, it becomes possible to state whether studies that address scientific evidence on the component elements of instructorled oral debriefing are methodologically adequate and reliable.

\section{Study limitations}

Through the search strategies applied and the information sources consulted, limited production on the topic of interest was found, which points to the need for scientific deepening in terms of the theme for the teaching and learning process in nursing.

\section{Contributions to the field of nursing}

This study contributes to teaching, research, and assistance, within the scope of clinical health simulation, by identifying, defining, and presenting the main elements of the instructor-led oral 
debriefing technique, its benefits, and challenges for adoption, facilitating the planning of teachers and instructors in the field of nursing. Still, it favors the execution of the technique, in an excellence teaching and learning process, as well as presenting the evaluation of the methodological quality of the research that comprised the sample.

\section{FINAL CONSIDERATIONS}

As for the instructor-led oral debriefing technique, three main categories were highlighted: Component elements; Benefits; and Challenges for adoption.

The main elements that make it possible are the instructor's characteristics; the format of the discussion; the debriefing structure/ procedure; and the time needed for execution. The identification of these components supports the adequate adoption of this debriefing technique, which, despite being considered common in literature, is only cited and not detailed by most scientific studies. More benefits than challenges were identified for the technique in question.

The main benefit highlighted by the literature was characterized by the development of cognitive and psychomotor skills in nursing, more significantly in this technique than in others. The main challenge, on the other hand, was the need to obtain adequate training for the facilitator, given the large number of students in nursing schools, which exceeds the institutions capacity to adequately prepare professionals. The studies that comprised the sample presented, in their totality, high methodological quality; however, due to the scarce production on the theme, it is suggested that further research that deepens the subject of the execution of oral debriefing guided by instructors be developed.

\section{REFERENCES}

1. Bi M, Zhao Z, Yang J, Wang Y. Comparison of case-based learning and traditional method in teaching postgraduate students of medical oncology. Medical Teacher. 2019;41(10):1124-8. https://doi.org/10.1080/0142159X.2019.1617414

2. Dickinson BL, Lackey W, Sheakley M, Miller L, Jevert S, Shattuck B. Involving a real patient in the design and implementation of case-based learning to engage learners. Adv Physiol Educ. 2018;42(1):118-22. https://doi.org/10.1152/advan.00174.2017

3. Ilkiw JE, Nelson RW, Watson JL, Conley AJ, Raybould HE, Chigerwe M, et al. Curricular revision and reform: the process, what was important, and lessons learned. J Vet Med Educ. 2017;44(3):480-9. https://doi.org/10.3138/jvme.0316-068R

4. Lavoiea P, Pepina J, Cossettea S, Clarke SP. Debriefing approaches for high-fidelity simulations and outcomes related to clinical judgment in baccalaureate nursing students. Collegian. 2018. https://doi.org/10.1016/j.colegn.2019.01.001

5. Raman S, Labrague LJ, Arulappan J, Natarajan J, Amirtharaj A, Jacob D. Traditional clinical training combined with high-fidelity simulation based activities improves clinical competency and knowledge among nursing students on a maternity nursing course. Nurs Forum. 2019;54:434-40. https://doi.org/10.1111/nuf.12351

6. INACSL Standards Committee. INACSL standards of best practice: simulation debriefing. Clin Simul Nurs. 2016;12;S21-S25. https://doi. org/10.1016/ j.ecns.2016.09.008

7. Kang K, Yu M. Comparison of student self-debriefing versus instructor debriefing in nursing simulation: a quasi-experimental study. Nurse Educ Today. 2018;65:67-73. https://doi.org/10.1016/j.nedt.2018.02.030

8. Isaranuwatchai W, Alam F, Hoch J, Boet S. A cost-effectiveness analysis of self-debriefing versus instructor debriefing for simulated crises in perioperative medicine in Canada. J Educ Eval Health Prof. 2016;13:44. https://doi.org/10.3352/jeehp.2016.13.44

9. Roh YS, Kelly M, Ha EH. Comparison of instructor-led versus peer-led debriefing in nursing students. Nurs Health Sci. 2016;18(2);238-45. https://doi.org/10.1111/nhs.12259

10. Mendes KD, Silveira RC, Galvão CM. Revisão Integrativa: método de pesquisa para a incorporação de evidências na saúde e na enfermagem. Texto Contexto Enferm. 2008;17(4):758-64. https://doi.org/10.1590/S0104-07072008000400018

11. Ouzzani M, Hammady H, Fedorowicz Z, Elmagarmid A. Rayyan a web and mobile app for systematic reviews. Syst Rev. 2016;5(1):210. https:// doi.org/10.1186/s13643-016-0384-4

12. Ursi ES, Galvão CM. Prevenção de lesões de pele no perioperatório: revisão integrativa da literatura. Rev Latino-Am Enfermagem [Internet]. 2006 [cited 2020 Jan 9];14(1):124-31. Available from: http://www.scielo.br/pdf/rlae/v14n1/v14n1a17

13. Melnyk BM, Fineout-Overholt E. Evidence-based practice in nursing \& healthcare: a guide to best practice. 2. ed. Philadelphia: Wolters Kluwer Health/Pippincott Williams \& Wilkins; 2011.

14. Joanna Briggs Institute. JBI Reviewer's Manual. The Joanna Briggs Institute Critical Appraisal tools for use in JBI Systematic Reviews Checklist for Quasi-Experimental Studies (non-randomized experimental studies)[Internet]. 2017[cited 2020 Jan 9]. Available from: https:// joannabriggs.org/sites/default/files/2019-05/JBI_Quasi-Experimental_Appraisal_Tool2017_0.pdf

15. Moher D, Liberati A, Tetzlaff J, Altman DG, PRISMA Group. Preferred reporting items for systematic reviews and metaanalyses: the PRISMA statement. PLoS Med. 2009;6(7):e1000097. https://doi.org/10.1371/journal.pmed.1000097

16. Kim SK, Gagne JC. Instructor-led vs. peer-led debriefing in preoperative care simulation using standardized patients. Nurse Educ Today. 2018;71:34-9. https://doi.org/10.1016/j.nedt.2018.09.001 
17. Ha Eun-Ho, Lim EJ. Peer-Led written debriefing versus instructor-led oral debriefing: using multimode simulation. Clin Simul Nurs. 2018;18:38-46. https://doi.org/10.1016/j.ecns.2018.02.002

18. Ryoo EN, Ha EH. The importance of debriefing in simulation-based learning: comparison between debriefing and no debriefing. Comput Inform Nurs. 2015;33(12):538-45. https://doi.org/10.1097/CIN.0000000000000194

19. Brandão CF, Cecilio-Fernandes D. Importance and challenges of simulation training in healthcare. Sci Med. 2018;28(1):ID30102. https://doi. org/10.15448/1980-6108.2018.1.30102

20. Cheng A, Grant V, Huffman J, Burgess G, Szyld D, Robinson T, et al. Coaching the debriefer peer coaching to improve debriefing quality in simulation programs. Simul Healthc. 2017;12(5):319-25. https://doi.org/10.1097/SIH.0000000000000232

21. Sawyer T, Eppich W, Brett-Fleegler M, Grant V, Cheng A. More than one way to debrief: a critical review of healthcare simulation debriefing methods. Simul Healthc. 2016;11(3):209-17. https://doi.org/10.1097/SIH.0000000000000148

22. Loo ME, Krishnasamy C, Lim WS. Considering face, rights, and goals. a critical review of rapport management in facilitator-guided simulation debriefing approaches. Simul Healthc. 2018;13(1):52-60. https://doi.org/10.1097/SIH.0000000000000258

23. Phrampus PE, O'Donnell JM. Debriefing using a structured and supported approach. In: Levine AI. (Ed.). The comprehensive textbook of healthcare simulation. 2013. https://doi.org/10.1007/978-1-4614-5993-4_6

24. Kim M, Sunghee K. Debriefing practices in simulation-based nursing education in South Korea. Clin Simul Nurs. 2017;13(5):201-9. https:// doi.org/10.1016/j.ecns.2017.01.008

25. Waznonis AR. Simulation debriefing practices in traditional baccalaureate nursing programs: national survey results. Clin Simul Nurs. 2015;11(2):110-9. https://doi.org/10.1016/j.ecns.2014.10.002

26. Kim J, Park J, Shin S. Effectiveness of simulation-based nursing education depending on fidelity: a meta-analysis. BMC Med Educ [Internet]. 2016 [cited 2019 Oct 17];23(16):152. Available from: http://bmcmededuc.biomedcentral.com/articles/10.1186/ s12909-016-0672-7

27. Bronson S. Autonomy support environment and autonomous motivation on nursing student academic performance: an exploratory analysis. Nurse Educ Today. 2016;44:103-8. https://doi.org/10.1016/j.nedt.2016.05.013

28. Suen WQ, Lim S, Wang W, Kowitlawakul Y. Stressors and expectations of undergraduate nursing students during clinical practice in Singapore. Int J Nurs Pract. 2016;22(6):574-83. https://doi.org/10.1111/ijn.12473

29. Bublitz S, Guido LA, Lopes LF, Freitas EO. Association between nursing students' academic and sociodemographic characteristics and stress. Texto Contexto Enferm. 2016;25(4):e2440015. https://doi.org/10.1590/0104-07072016002440015

30. Boostel R, Felix JV, Bortolato-Major C, Pedrolo E, Vayego SA, Mantovani MA. Estresse do estudante de enfermagem na simulação clínica: ensaio clínico randomizado. Rev Bras Enferm. 2018;71(3):1029-37. https://doi.org/10.1590/0034-7167-2017-0187

31. Gönenç IM, Yılmaz Sezer N. Evaluation of the effectiveness of four different training techniques in the development of non-stress testing application skills: a randomised controlled trial. Nurse Educ Today. 2019;76:118-124. https://doi.org/10.1016/j.nedt.2019.01.030

32. Galvão TF, Silva MT, Garcia LP. Ferramentas para melhorar a qualidade e a transparência dos relatos de pesquisa em saúde: guias de redação científica. Epidemiol Serv Saúde. 2016;25:427-36. https://doi.org/10.5123/s1679-49742016000200022

33. Dutra HS, Reis VN. Experimental and quasi-experimental study designs: definitions and challenges in nursing research. Rev Enferm UFPE. 2016;10(6):2230-41. https://doi.org/10.5205/reuol.9199-80250-1-SM1006201639 